\title{
Hereditary North American Indian childhood cirrhosis
}

INSERM

\section{Source}

INSERM. (1999). Orphanet: an online rare disease and orphan drug data base. Hereditary North American Indian childhood cirrhosis. ORPHA:168583

Hereditary North American Indian childhood cirrhosis is a severe autosomal recessive intrahepatic cholestasis that has only been described in aboriginal children from northwestern Quebec. Manifesting first as transient neonatal jaundice, the disease evolves into periportal fibrosis and cirrhosis during a period rang ing from childhood to adolescence. 